\title{
Pengaruh Pemediasi Komitmen Organisasional dalam Hubungan antara Budaya Organisasi dengan Intent to Leave
}

\author{
Lintang Anugrah Nasution \\ lintangnasution01@gmail.com \\ Universitas Harapan Medan \\ T. Lyza T. Chairunnisa \\ tengkulyza@gmail.com \\ Universitas Harapan Medan \\ Sunaryo \\ sunaryo.dosen@gmail.com \\ Universitas Harapan Medan
}

\begin{abstract}
This study aims to determine the effect of organizational culture on organizational commitment, organizational culture on Intent to Leave, organizational commitment to Intent to Leave and organizational culture on Intent to Leave through organizational commitment. The population in this study were 114 respondents and using saturated sampling techniques. The analysis technique used is path analysis. The results showed that organizational culture has a positive and significant effect on organizational commitment, organizational culture has a positive and significant effect on intent to leave, organizational commitment has no significant effect on intent to leave and there is no direct influence between organizational culture on intent to leave through organizational commitment.
\end{abstract}

Keywords : intent to leave, organizational commitment, organizational culture

\section{Pendahuluan}

Pengelolaan sumber daya manusia dalam perusahaan tidaklah cukup dengan hanya memiliki program perekrutan yang baik atau pelatihan dan pengembangan sumber daya manusia dalam rangka meningkatkan kemampuan individu karyawan dalam perusahaan, akan tetapi suatu program untuk menjaga kepuasan setiap individu karyawan terhadap pekerjaan yang menjadi tanggung jawabnya, menjaga dan membangun komitmen karyawan terhadap perusahaan, dan dari semua hal tersebut diharapkan mampu mempertahankan sumber daya manusia yang berkualitas dan memiliki kinerja tinggi untuk tetap berada di dalam perusahaan, adalah bagian penting dari pengelolaan sumber daya manusia dalam perusahaan. Tercapainya keberhasilan dalam suatu organisasi tidak bisa terlepas dari peranan setiap sumber daya manusia dalam perusahaan tersebut, untuk itu setiap organisasi ataupun perusahaan yang menyadari betapa pentingnya sumber daya manusia yang berkualitas untuk kemajuan perusahaan, berusaha mengelola dengan baik sumber daya manusia yang dimilikinya agar mampu mencapai target-target yang sebelumnya telah ditetapkan dalam perusahaan.

Suatu budaya yang kuat akan memperlihatkan kesepakatan yang tinggi mengenai tujuan organisasi di antara anggota-anggotanya. Kebulatan suara terhadap tujuan akan membentuk keterikatan, kesetiaan, dan komitmen organisasi, kondisi ini selanjutnya akan mengurangi kecenderungan karyawan untuk keluar dari organisasi (Robins, 2014). Ada banyak karyawan yang puas dengan pekerjaan mereka, tetapi mereka tidak menyukai banyaknya birokrasi organisasi di mana mereka bekerja, atau teknisi yang tidak puas dengan pekerjaannya, tetapi tetap menjalankan visi perusahaan (Luthans, 2012). 
Peran budaya dalam mempengaruhi perilaku karyawan tampaknya makin penting di tempat kerja saat ini, makna bersama yang diberikan oleh budaya yang kuat memastikan bahwa semua karyawan diarahkan ke arah yang sama, budaya meningkatkan komitmen organisasional dan meningkatkan konsistensi perilaku karyawan (Robins, 2014). Adanya niat berpindah karyawan diindikasikan disebabkan oleh permasalahan seperti kepuasan kerja, tekanan dari atasan, persaingan antar karyawan dan masalah eksternal seperti adanya tawaran kerja di perusahaan lain yang lebih baik (Prihartono, 2013). Fenomena yang berkembang di dalam perusahaan bahwa karyawan sering menyampaikan keluhan terkait dengan ketidaknyamanan yang mereka rasakan. Diantaranya adalah karyawan merasa bahwa pengelolaan sumber daya manusia di dalam perusahaan belum termasuk dalam kategori yang baik. Hal ini di sebabkan oleh pimpinan mereka yang bersifat terlalu otoriter, serta kurang terjalinnya rasa kekeluargaan antara jajaran atasan dengan karyawan, sehinggahal tersebut seringkah membuat karyawan menjadi tidak nyaman dan merasa tidak terikat secara emosional terhadap perusahaan.

PT. Fast Food Indonesia Tbk. Medan adalah salah satu perusahaan yang bergerak dalam bidang makanan, hal tersebut menjadi salah satu alasan untuk melihat lebih jauh apakah budaya organisasi akan mempengaruhi tingkat keinginan dari karyawan keluar atau berpindah ke perusahaan yang lain dengan mengacu pada proses terbentuknya budaya organisasi. Terbentuknya budaya organisasi dimulai dari filosofi pendiri yang selanjutnya akan mempengaruhi kriteria dalam penerimaan karyawan, kemudian tindakan manajemen puncak akan membentuk iklim umum mengenai perilaku yang dapat diterima dan yang tidak dapat diterima. Baik buruknya keberhasilan atau pencapaian pada tujuan perusahaan dibutuhkan komitmen yang kuat dari setiap karyawan. Komitmen karyawan dapat dilihat dari keseriusan karyawan untuk bersama dan bertahan bekerja pada perusahaan.

Budaya yang dapat menyesuaikan dan mendorong keterlibatan karyawan, dapat memperjelas tujuan dan arah strategis organisasi, serta yang senantiasa menguraikan dan mengajarkan nilai-nilai dan keyakinan organisasi, dapat membantu perusahaan mencapai pertumbuhan penjualan, keuntungan, mutu, dan kepuasan pelanggan yang lebih tinggi. Pengganti perilaku, penambahan perilaku dan perubahan benda-benda perlambang adalah caracara yang dapat dilakukan oleh manajer untuk memulai penambahan budaya organisasi.

Karakteristik budaya kerja sangat dipengaruhi oleh beberapa faktor yang disebutkan di atas. Fenomena yang berkembang di dalam perusahaan menunjukkan penurunan komitmen yang disebabkan oleh beberapa hal, seperti perilaku pegawai secara individu kurang perduli terhadap hasil kerjanya sehingga menyebabkan kegiatan dalam pekerjaannya di kantor menjadi tidak optimal, dan ini sudah menjadi sifat pegawai yang tentunya hams dihindari. Kurangnya keharmonisan dan kesetiaan berupa penghargaan kepada karyawan yang berprestasi sehingga muncul keinginan untuk berpindah ke tempat kerja yang lain. Adaptasi atau penyesuaian terhadap pekerjaan yang baru tidak berjalan karena kurangnya dukungan dari rekan kerja serta berbagai macam budaya, agama di antara karyawan itu sendiri menyebabkan penyesuaian yang terjadi tidak berjalan sebagaimana mestinya.

Intention to leave dimediasi oleh beberapa faktor yang antara lain adalah komitmen organisasional. Komitmen organisasional merupakan suatu keadaaan di mana seorang karyawan memihak organisasi tertentu serta tujuan-tujuan dan keinginannya untuk mempertahankan keanggotaan dalam organisasi tersebut (Robbins \& Judge, 2014). Komitmen dari seorang karyawan terhadap organisasinya dapat menjadi instrumen penting untuk meningkatkan kinerja dari karyawan tersebut.Komitmen organisasional juga memiliki keterkaitan dengan karakteristik pekerjaan. Keharmonisan tujuan yang tercapai antara karyawan dan organisasi melalui budaya akan membangun suatu komitmen organisasional dalam diri karyawan. Rendahnya komitmen normatif diindikasikan dari kurangnya kesetiaan karyawan untuk tetap bekerja di PT. Fast Food Indonesia Tbk. Medan. Beberapa karyawan akan tetap bertahan atau tetap bekerja jika kesejahteraan/gajinya ditingkatkan/sebanding dengan pekerjaan yang dilakukannya. Ada banyak karyawan yang puas dengan pekerjaan mereka, tetapi mereka tidak menyukai banyaknya birokrasi organisasi di mana mereka bekerja, atau teknisi yang tidak puas dengan pekerjaannya, tetapi tetap menjalankan visi perusahaan. Peran budaya dalam mempengaruhi perilaku karyawan tampaknya makin penting di tempat kerja saat ini, 
makna bersama yang diberikan oleh budaya yang kuat memastikan bahwa semua karyawan diarahkan ke arah yang sama, budaya meningkatkan komitmen organisasional dan meningkatkan konsistensi perilaku karyawan (Robins, 2014).

Selain itu Meyer et al. (1993) dalam Siswanti (2006) menemukan bahwa komitmen afektif dan komitmen normatif mempunyai hubungan negatif dengan keinginan untuk meninggalkan organisasi, tetapi komitmen continuance tidak signifikan mempengaruhi turnover intention. Penelitian Clugston (2000) dalam Siswanti (2006) dengan analisis path menemukan bahwa komitmen afektif dan komitmen continuance mempengaruhi intent to leave secara negatif signifikan, serta komitmen normatif tidak signifikan mempengaruhi intent to leave.

Permasalahan di atas juga didukung dengan rendahnya komitmen yang diindikasikan ketika ada pengawasan dari atasan hampir seluruh karyawan bekerja dengan sebaik-baiknya, akan tetapi pada saat tidak diawasi para karyawan akan bekerja dengan sekehendak hatinya. Hal ini mengindikasikan bahwa karyawan belum sepenuhnya percaya pada perusahaan dan bersedia menerima nilai-nilai perusahaan. Rendahnya komitmen berkesinambungan diindikasikan ketika ada beberapa karyawan yang memiliki keinginan atau perasaan untuk pindah, jika ada tawaran pekerjaan yang lebih ringan dan tidak seberat bekerja di perusahaan dengan penawaran gaji yang lebih tinggi. Hal ini mengindikasikan bahwa karyawan belum sepenuhnya membutuhkan pekerjaan yang dijalani di PT. Fast Food Indonesia Tbk. Medan.

Pemahaman tentang arti komitmen organisasi sangat penting bagi karyawan agar tercipta kondisi keija yang kondusif sehingga perusahaan dapat berjalan secara efisien dan efektif. Ada beberapa alasan mengapa organisasi harus melakukan berbagai usaha untuk meningkatkan derajat komitmen organisasi dalam diri karyawan. Pertama, semakin tinggi komitmen organisasional, semakin besar pula usaha yang dilakukan karyawan dalam melaksanakan pekerjaan. Kedua, semakin tinggi komitmen organisasional, maka semakin lama pula ia ingin tetap berada dalam organisasi. Dengan kata lain, jika karyawan mempunyai komitmen organisasional yang tinggi, maka ia tidak berniat meninggalkan organisasi.

Penelitian ini merupakan replikasi dari penelitian yang dilakukan oleh Siswanti (2006). Persamaan dalam penelitian ini adalah variabel Z (komitmen organisasional) dan Y (Intent to Leave). Sedangkan perbedaannya adalah variabel $\mathrm{X}$ yaitu budaya organisasi.

\section{Kajian Pustaka}

\subsection{Pengertian Intent to Leave}

Pengertian intent to leave adalah keinginan seseorang untuk berpindah dari perusahaan semula bekerja ke perusahaan lain. Menurut Mathis \& Jackson (2012), jenis turnover dikelompokkan dalam turnover secara tidak sukarela dan turnover secara sukarela. Faktor penyebab turnover menurut Armstrong (2016) adalah gaji/upah, desain pekerjaan, pelatihan dan pengembangan, perkembangan karir, komitmen, kurangnya kekompakan, ketidakpuasan dan bermasalah dengan atasan atau pengawas, rekrutmen, seleksi dan promosi

\subsection{Indikator Intent to Leave}

Mangkunegara (2011) menyatakan bahwa indikator Intent to Leave yaitu:

a. Intention to quit (niat untuk keluar).

b. Job search (pencarian pekerjaan).

c. Thinking of quit (memikirkan keluar).

\subsection{Pengertian Budaya Organisasi}

Menurut Robins (2014), budaya organisasi adalah seperangkat nilai-nilai, keyakinan, dan sikap utama yang diberlakukan di antara anggota organisasi. Budaya organisasi sering kali diciptakan oleh pendiri perusahaan, kemudian dipertahankan dengan cara memberitahukan riwayat organisasi dan merayakan kepahlawanan organisasi. Budaya yang dapat menysuaikan dan mendorong keterlibatan karyawan, dapat memperjelas tujuan dan arah startegis organisasi, serta yang senantiasa menguraikan dan mengajarkan nilai-nilai dan keyakinan organisasi, dapat membantu perusahaan mencapai pertumbuhan penjualan, pengembalian modal, keuntungan, mutu, dan kepuasan pelanggan yang lebih tinggi. Pengganti perilaku, penambahan perilaku dan 
perubahan benda-benda perlambang adalah cara-cara yang dapat dilakukan oleh manajer untuk memulai perubahan budaya organisasi.

\subsection{Indikator Budaya Organisasi}

Menurut Harrison dalam Sobirin (2019), ada 4 (empat) indikator budaya organisasi:

a. Power Culture.

b. Role Culture

c. Achievement Culture

d. Support Culture

\subsection{Pengertian Komitmen Organisasional}

Komitmen organisasional merupakan tingkat sampai mana seorang karyawan memihak sebuah organisasi serta tujuan-tujuan dan keinginannya untuk mempertahankan keanggotaan dalam organisasi tersebut (Robbins \& Judge, 2014). Keterlibatan pekerjaan yang tinggi berarti memihak pada pekerjaan tertentu seorang individu, sementara komitmen organisasional yang tinggi berarti memihak organisasi yang merekrut individu tersebut. Komitmen organisasi yang dimaksudkan dalam penelitian ini adalah komitmen organisasi merupakan bagaimana karyawan mengenal, mengindentifkasi dan memihak organisasi, serta berkeinginan untuk tetap tinggal dalam organisasi dalam menjalankan tujuan organisasi.

\subsection{Indikator Komitmen Organisasional}

Demiray et al. dalam Prihartono (2013) menyebutkan bahwa untuk mengukur komitmen organisasi dari karyawan dapat diukur dengan:

a. Affective Commitment yaitu keterlibatan emosi pekerja dengan organisasi

b. Continuence Commitment merupakan keterlibatan komitmen berdasarkan biaya yang dikeluarkan akibat keluarnya pekerja dari organisasi.

c. Normative Commitment keterlibatan perasaan pekerja terhadap tugas-tugas yang ada di organisasi.

\section{Metodelogi Penelitian}

\subsection{Jenis Penelitian}

Penelitian ini menggunakan jenis penelitian asosiatif kausalitas. Asosiatif merupakan penelitian yang bertujuan untuk mengetahui pengaruh dua variabel $X$ atau lebih terhadap variabel Y (Sugiyono, 2012). Sedangkan kausalitas adalah sebuah hubungan yang terjadi antara dua variabel atau lebih, namun hubungan tersebut didasari atas hubungan kausalitas atau hubungan sebab-akibat. Dalam penelitian ini bertujuan mengetahui pengaruh pemediasi komitmen organisasional dalam hubungan budaya organisasi dengan intent to leave dan untuk mengetahui hubungan sebab akibat pemediasi komitmen organisasional dalam hubungan budaya organisasi dengan intent to leave pada PT. Fast Food Indonesia Tbk. Medan.

\subsection{Teknik Analisis Data}

\subsubsection{Persamaan Model}

Untuk mengetahui pengaruh atau hubungan variabel bebas (budaya organisasi) dengan variabel terikat (intent to leave) melalui komitmen organisasional, maka digunakan analisis data regresi linier berganda menggunakan aplikasi SPSS, rumusnya adalah sebagai berikut :

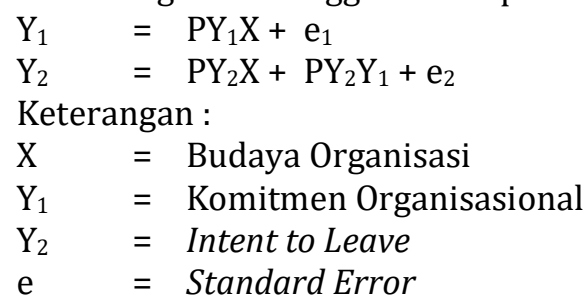




\subsubsection{Uji Fit (Kecocokan) Model}

Uji $\mathrm{F}$ bertujuan untuk menunjukkan apakah semua variabel bebas yang dimasukkan dalam model mempunyai pengaruh secara bersama-sama terhadap variabel terikat.Untuk mengetahui secara bersama-sama pengaruh variabel independen atau variabel bebas melakukan pengujian $\mathrm{F}$ terhadap variabel terkait.

$\mathrm{H}_{0}$ diterima, artinya secara bersama-sama tidak terdapat pengaruh yang artinya positif dan signifikan dari variabel bebas $(\mathrm{X})$ yaitu berupa variabel budaya organisasi terhadap Intent to Leave $(\mathrm{Y})$ variabel terikat. $\mathrm{H}_{1}$ diterima, artinya secara bersama-sama terdapat pengaruh yang positif dan signifikan dari variabel bebas $(\mathrm{X})$ yaitu berupa variabel budaya organisasi terhadap intent to leave $(\mathrm{Y})$ variabel terikat.

\subsubsection{Koefisien Determinasi $\left(\mathbf{R}^{2}\right)$}

Uji koefisien determinasi $\left(\mathrm{R}^{2}\right)$ pada intinya untuk mengukur seberapa jauh kemampuan model dalam menerangkan variasi variabel dependen/tidak bebas.Nilai dari koefisien determinasi adalah antara nol sampai satu $\left(0<\mathrm{R}^{2}<1\right)$ Nilai $\mathrm{R}^{2}$ yang kecil berarti kemampuan variabel-variabel independen (bebas) dalam menjalankan variabel dependen amat terbatas. Berarti jika $\mathrm{R}^{2}$ semakin besar (mendekati satu), maka dapat dikatakan bahwa pengaruh variabel bebas $(\mathrm{X})$ yaitu budaya organisasi adalah besar pengaruhnya terhadap variabel terikat $(\mathrm{Y})$ yaitu intent to leave. Nilai yang didekati satu berarti variabel-variabel independen memberikan hampir semua informasi yang dibutuhkan untuk memprediksi variabel dependen.Proporsi atau persentase sumbangan variabel bebas dalam menerangkan variabel terikat.

$\mathrm{KD}=\mathrm{r}^{2} \times 100 \%$

\section{Analisis dan Pembahasan}

\subsection{Analisis Jalur (Path Analysis)}

\subsubsection{Sub Struktur I}

a. Uji Asumsi Klasik

1) Pengujian Normalitas Data

Tabel 3. Hasil Uji Kolmogorov Smirnov Model Persamaan 1

\begin{tabular}{|ll|r|}
\hline & & \multicolumn{1}{|c|}{ Unstandardized Residual } \\
\hline $\mathrm{N}$ & & 114 \\
Normal Parametersa,b & Mean &, 0000000 \\
& Std. Deviation & 1,67710885 \\
Most Extreme Differences & Absolute &, 124 \\
& Positive &, 103 \\
& Negative &,- 124 \\
Kolmogorov-Smirnov Z & & 1,329 \\
Asymp. Sig. (2-tailed) & &, 058 \\
\hline
\end{tabular}

Sumber : Data Primer Diolah, 2020.

Berdasarkan hasil uji normalitas dengan Kolmogorov-Smirnov Model persamaan diperoleh nilai KSZ sebesar 1,329 dan Asyimp. Sig sebesar 0,058 lebih besar dari 0,05, maka dapat disimpulkan data berdistribusi normal.

\section{2) Pengujian Heteroskedastisitas}

Tabel 4. Uji Glejser Model Persamaan I

\begin{tabular}{|c|c|c|c|c|c|}
\hline \multirow[t]{2}{*}{ Model } & \multicolumn{2}{|c|}{$\begin{array}{c}\text { Unstandardized } \\
\text { Coefficients }\end{array}$} & $\begin{array}{c}\text { Standardized } \\
\text { Coefficients }\end{array}$ & \multirow[b]{2}{*}{$\mathrm{t}$} & \multirow[b]{2}{*}{ Sig. } \\
\hline & $\mathrm{B}$ & Std. Error & Beta & & \\
\hline $\begin{array}{ll}1 & \text { (Constant) }\end{array}$ & 4,631 & ,651 & & 7,119 & 000 \\
\hline Budaya Organisasi &,- 206 & ,038 &,- 453 & $-1,375$ & ,223 \\
\hline
\end{tabular}

a. Dependent Variable: Abs_Res

Sumber : Data Primer Diolah, 2020 
Berdasarkan Tabel 4 di atas, diketahui nilai signifikansi (Sig.) untuk variabel budaya organisasi $(X)$ adalah 0,223. Karena nilai signifikansi variabel budaya organisasi (X) lebih besar dari 0,05, maka sesuai dengan dasar pengambilan keputusan dalam uji glejser, dapat disimpulkan bahwa tidak terjadi gejala heteroskedastisitas dalam model regresi.

\section{b. Pengujian Kelayakan Model Analisis Jalur Substruktur I}

Tabel 5. Pengujian Kelayakan Model Persamaan I

ANOVA $^{\mathrm{b}}$

\begin{tabular}{|c|c|c|c|c|c|}
\hline Model & Sum of Squares & $\mathrm{df}$ & Mean Square & $\mathrm{F}$ & Sig. \\
\hline 1 Regression & 288,271 & 1 & 288,271 & 091,582 &, $000^{\mathrm{a}}$ \\
\hline Residual & 317,834 & 112 & 2,838 & & \\
\hline Total & 606,105 & 113 & & & \\
\hline
\end{tabular}

a. Predictors: (Constant), Budaya Organisasi

b. Dependent Variable: Komitmen Organisasional

Sumber : data primer diolah, 2020.

Nilai probabilitas pengujian adalah sebesar 0,000 nilai tersebut lebih kecil dari 0,05 $(0,000<0,05)$. Hal ini menunjukkan bahwa model analisis jalur substruktur I telah fit.

\section{c. Pengujian Koefisien Determinasi $\left(\mathbf{R}^{2}\right)$}

Tabel 6. Koefisien Determinasi Model Persamaan 1 Model Summaryb

\begin{tabular}{|l|r|r|r|r|}
\hline Model & $\mathrm{R}$ & R Square & \multicolumn{1}{|c|}{ Adjusted R Square } & \multicolumn{1}{c|}{ Std. Error of the Estimate } \\
\hline 1 &, $690^{\mathrm{a}}$ &, 476 &, 471 & 1,68459 \\
\hline
\end{tabular}

Sumber : data primer diolah, 2020.

Nilai R Square menunjukkan nilai 0,476 artinya bahwa kemampuan variabel budaya organisasi menjelaskan komitmen organisasional adalah sebesar 47,6\% sedangkan sisanya sebesar 0,524 atau 52,4\% merupakan nilai error variabel model substruktur I.

\section{d. Pengujian Hipotesis}

Tabel 7. Pengujian Hipotesis Model Persamaan 1

Coefficients $^{\mathbf{a}}$

\begin{tabular}{|c|c|c|c|c|c|}
\hline \multirow[t]{2}{*}{ Model } & \multicolumn{2}{|c|}{$\begin{array}{c}\text { Unstandardized } \\
\text { Coefficients }\end{array}$} & Standardized Coefficients & & \\
\hline & $\mathrm{B}$ & Std. Error & Beta & $\mathrm{t}$ & Sig. \\
\hline $\begin{array}{ll}1 & \text { (Constant) } \\
& \text { Budaya Organisasi }\end{array}$ & $\begin{array}{r}2,028 \\
, 611\end{array}$ & $\begin{array}{r}1,028 \\
, 061\end{array}$ & 690 & $\begin{array}{r}1,973 \\
10,079\end{array}$ & $\begin{array}{l}, 051 \\
, 000\end{array}$ \\
\hline
\end{tabular}

a. Dependent Variable: Komitmen Organisasional

Sumber : data primer diolah, 2020.

Tabel 7 di atas menunjukkan bahwa nilai probabilitas (p) budaya organisasi adalah 0,000. Jika dibandingkan dengan nilai Alpha $(0,05)$, maka dapat ditetapkan bahwa probabilitas $<$ Alpha $(\mathrm{p}<0,05)$, sehingga dapat disimpulkan bahwa budaya organisasi berpengaruh signifikan terhadap komitmen organisasional. Besarnya nilai budaya organisasi mempengaruhi komitmen organisasional adalah sebesar 0,690. 
e. Gambar Model Analisis Jalur Substruktur I

$$
\mathrm{PY}_{1} \mathrm{X}=0,690
$$

$$
\mathrm{e}_{1}=0,524
$$

Budaya Organisasi (X)

Komitmen Organisasional $\left(\mathrm{Y}_{1}\right)$

\section{Gambar 1. Model Analisis Jalur Substruktur I}

$$
Y_{1}=0,690 P Y_{1} X+0,524 e_{1}
$$

\subsubsection{Sub Struktur II}

a. Uji Asumsi Klasik

1) Pengujian Normalitas Data

Tabel 8. Hasil Uji Kolmogorov Smirnov Model Persamaan II One-Sample Kolmogorov-Smirnov Test

\begin{tabular}{|ll|r|}
\hline & & \multicolumn{1}{|c|}{ Unstandardized Residual } \\
\hline $\mathrm{N}$ & & 114 \\
Normal Parameters ${ }^{\mathrm{a}} \mathrm{b}$ & Mean &, 0000000 \\
& Std. Deviation & 1,66831284 \\
Most Extreme Differences & Absolute &, 123 \\
& Positive &, 096 \\
& Negative &,- 123 \\
Kolmogorov-Smirnov Z & & 1,309 \\
Asymp. Sig. (2-tailed) & &, 065 \\
\hline
\end{tabular}

a. Test distribution is Normal.

b. Calculated from data.

Sumber : Data Primer Diolah, 2020.

Berdasarkan hasil uji normalitas dengan Kolmogorov-Smirnov Model persamaan diperoleh nilai KSZ sebesar 1,309 dan Asyimp. Sig sebesar 0,065 lebih besar dari 0,05, maka dapat disimpulkan data berdistribusi normal.

2) Pengujian Multikolinieritas

Tabel 9. Hasil Uji Multikolinearitas Model Persamaan II

\begin{tabular}{|l|l|c|c|}
\hline \multicolumn{2}{|c|}{ Model } & \multicolumn{2}{c|}{ Collinearity Statistics } \\
\cline { 3 - 4 } & & Tolerance & VIF \\
\hline 1 & Budaya organisasi & .316 & 3.164 \\
2 & Komitmen organisasional & .316 & 3.164 \\
\hline
\end{tabular}

a. Dependent Variable : intent to leave

Sumber : data primer diolah, 2020.

3) Pengujian Heteroskedastisitas

Tabel 10. Uji Glejser Model Persamaan II

Coefficients ${ }^{\mathrm{a}}$

\begin{tabular}{|ll|r|r|r|r|r|}
\hline \multirow{2}{*}{ Model } & \multicolumn{3}{|c|}{$\begin{array}{c}\text { Unstandardized } \\
\text { Coefficients }\end{array}$} & Standardized Coefficients & & \\
& \multicolumn{1}{|c|}{$\mathrm{B}$} & Std. Error & Beta & \multicolumn{1}{c|}{ t } & Sig. \\
\cline { 2 - 6 } & (Constant) & 4,663 &, 652 & & 7,151 &, 000 \\
& Budaya Organisasi &, 254 &, 068 &, 555 & 1,706 &, 068 \\
& Intent to Leave &, 061 &, 077 &, 118 &, 786 &, 434 \\
\hline
\end{tabular}

a. Dependent Variable: Abs_Res

Sumber : Data Primer Diolah, 2020. 
Berdasarkan Tabel 10 di atas, diketahui nilai signifikansi (Sig.) untuk variabel budaya organisasi $(X)$ adalah 0,068 dan nilai signifikansi (Sig.) untuk variabel komitmen organisasional $\left(\mathrm{Y}_{1}\right)$ adalah 0,434 . Dapat disimpulkan bahwa nilai signifikansi variabel budaya organisasi $(\mathrm{X})$ $0.068>0,05$ dan nilai signifikansi variabel komitmen organisasional $\left(\mathrm{Y}_{1}\right) 0.434>0,05$, maka sesuai dengan dasar pengambilan keputusan dalam uji glejser, dapat disimpulkan bahwa tidak terjadi gejala heteroskedastisitas dalam model regresi.

\section{b. Pengujian Kelayakan Model Analisis Jalur Substruktur II}

Tabel 11. Pengujian Kelayakan Model Persamaan II

ANOVA $^{\mathrm{b}}$

\begin{tabular}{|c|c|c|c|c|c|}
\hline Model & Sum of Squares & $\mathrm{df}$ & Mean Square & $\mathrm{F}$ & Sig. \\
\hline 1 Regression & 291,596 & 2 & 145,798 & 51,457 &, $000^{\text {a }}$ \\
\hline Residual & 314,509 & 111 & 2,833 & & \\
\hline Total & 606,105 & 113 & & & \\
\hline
\end{tabular}

a. Predictors: (Constant), Intent to Leave, Budaya Organisasi

b. Dependent Variable: Komitmen Organisasional

Sumber : data primer diolah, 2020.

Nilai probabilitas pengujian adalah sebesar 0,000 nilai tersebut lebih kecil dari 0,05 $(0,000<0,05)$. Hal ini menunjukkan bahwa model analisis jalur substruktur II telah fit.

\section{c. Pengujian Koefisien Determinasi $\left(\mathbf{R}^{2}\right)$}

Tabel 12. Koefisien Determinasi Model Persamaan II Model Summaryb

\begin{tabular}{|l|r|r|r|r|}
\hline Model & $\mathrm{R}$ & R Square & Adjusted R Square & \multicolumn{1}{c|}{ Std. Error of the Estimate } \\
\hline 1 &, $694^{\mathrm{a}}$ &, 481 &, 472 & 1,68328 \\
\hline
\end{tabular}

a. Predictors: (Constant), Komitmen organisasional, Budaya organisasi

b. Dependent Variable: Intent to leave

Sumber : data primer diolah, 2020.

Nilai R Square menunjukkan nilai 0,481 artinya bahwa kemampuan budaya organisasi dan komitmen organisasional menjelaskan intent to leave adalah sebesar 48,1\%, sedangkan sisanya sebesar 0,519 atau 51,9\% merupakan nilai error variabel model substruktur II.

\section{d. Pengujian Hipotesis}

Tabel 13. Pengujian Hipotesis Model 2 Coefficientsa

\begin{tabular}{|c|c|c|c|c|c|}
\hline \multirow[t]{2}{*}{ Model } & \multicolumn{2}{|c|}{$\begin{array}{l}\text { Unstandardized } \\
\text { Coefficients }\end{array}$} & \multirow{2}{*}{$\begin{array}{c}\text { Standardized } \\
\text { Coefficients }\end{array}$} & \multirow[b]{2}{*}{$\mathrm{t}$} & \multirow[b]{2}{*}{ Sig. } \\
\hline & $\mathrm{B}$ & Std. Error & & & \\
\hline $1 \quad$ (Constant) & 2,030 & 1,027 & & 1,977 & 051 \\
\hline Budaya organisasi & ,515 & ,108 & ,581 & 4,774 & ,000 \\
\hline Komitmen organisasional & 132 & 122 & 132 & 1,083 & 281 \\
\hline
\end{tabular}

a. Dependent Variable: Intent to leave

Sumber : data primer diolah, 2020.

Tabel 1328 menunjukkan bahwa nilai probabilitas (p) budaya organisasi adalah 0,000, dan nilai probabilitas (p) komitmen organisasional adalah 0,281 . Jika dibandingkan dengan nilai Alpha $(0,05)$, maka dapat ditetapkan bahwa probabilitas lebih kecil dari nilai Alpha $(\mathrm{p}<0,05)$, sehingga dapat disimpulkan bahwa budaya organisasi berpengaruh signifikan terhadap intent to leave, sedangkan komitmen organisasional tidak berpengaruh signifikan terhadap intent to 
leave. Besarnya nilai budaya organisasi mempengaruhi intent to leave adalah sebesar 0,581, dan besarnya nilai komitmen organisasional mempengaruhi intent to leave adalah sebesar 0,132.

\section{e. Gambar Model Analisis Jalur Substruktur II}

Berdasarkan pada penjelasan pada substruktur II dapat digambarkan model analisis jalurnya sebagai berikut:

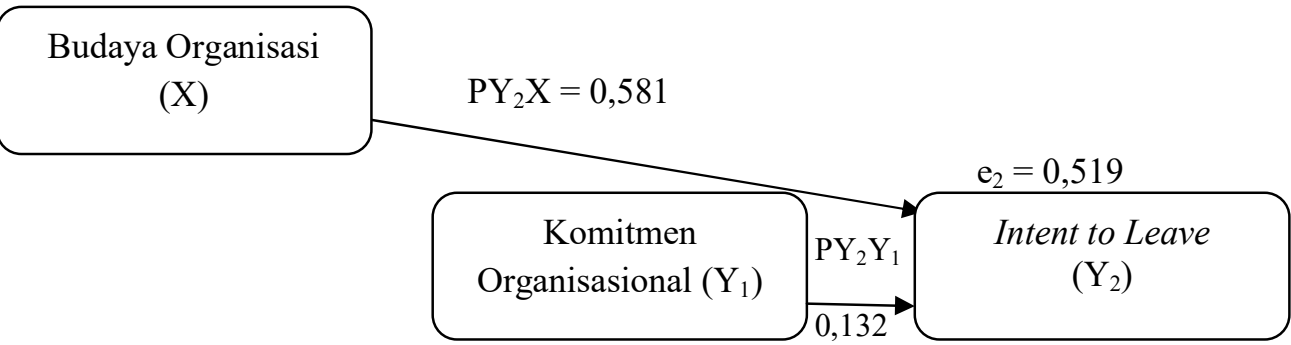

\section{Gambar 2. Model Analisis Jalur Substruktur II}

$$
\mathrm{Y}_{2}=0,581 \mathrm{PY}_{2} \mathrm{X}+0,132 \mathrm{PY}_{2} \mathrm{Y}_{1}+0,519 \mathrm{e}_{2}
$$

\subsection{Pengujian Pengaruh Tidak Langsung}

Untuk dapat informasi terkait dengan jawaban hipotesis tentang pengaruh tidak langsung pada penelitian ini yaitu Pengaruh budaya organisasi terhadap intent to leave melalui komitmen organisasional dapat digunakan pengujian Sobel berikut ini:

Tabel 14. Pengujian Sobel

\begin{tabular}{|c|c|c|c|c|c|}
\hline \multicolumn{2}{|c|}{ Input } & Test Statistic & Std. Error & p-value \\
\hline a & 0,690 & Sobel test & 1,0770513 & 0,0845642 & 0,2814574 \\
\hline b & 0,132 & Aroian test & 1,0729046 & 0,0848911 & 0,2833139 \\
\hline Sa & 0,061 & Goodman test & 1,0812464 & 0,0842361 & 0,2795875 \\
\hline Sb & 0,122 & Reset all & & Calculate \\
\hline
\end{tabular}

Sumber : data primer diolah, 2020.

Tabel di atas menunjukkan bahwa pada pengujian Sobel Test nilai probabilitasnya (pvalue)adalah 0,281lebih besar dari 0,05 $(0,281>0,05)$, sehingga dapat disimpulkan bahwa tidak terdapat pengaruh signifikan budaya organisasi terhadap intent to leave melalui komitmen organisasional. Besarnya pengaruh tidak langsung budaya organisasi terhadap intent to leave melalui komitmen organisasional adalah sebagai berikut: model analisis jalur pada penelitian ini adalah sebagai berikut:

$$
\mathrm{Y}_{1} \mathrm{X} \times \mathrm{pY}_{2} \mathrm{Y}_{1}=0,690 \times 0,132=0,091
$$

\subsection{Model Analisis Jalur}

Model analisis jalur pada penelitian ini adalah sebagai berikut :

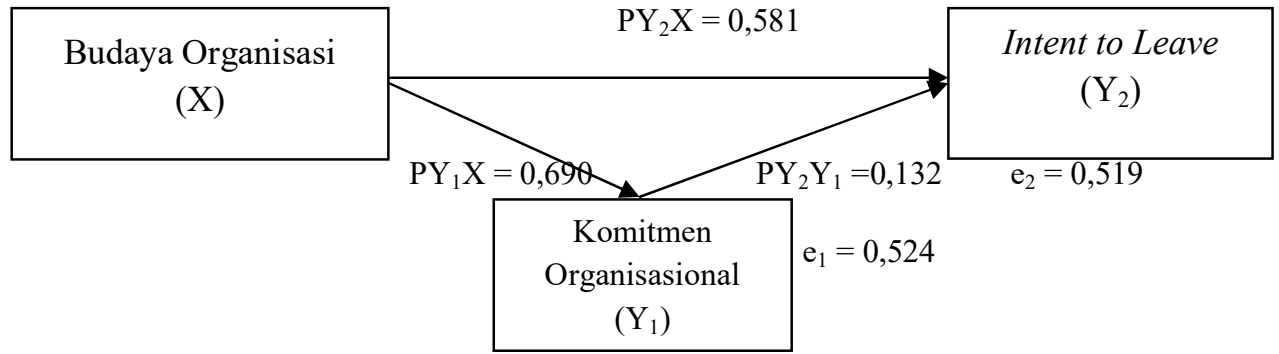

Gambar 3. Model Analisis Jalur Substruktur Analisis Jalur 
Berdasarkan gambar tersebut dan hasil penjelasan sebelumnya, maka dapat dihitung total pengaruh setiap variabel eksogen terhadap variabel endogennya. Total pengaruhnya adalah sebagai berikut:

Total Pengaruh Budaya organisasi Terhadap Intent to leave

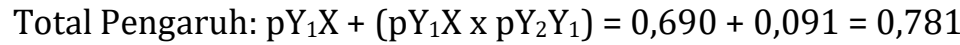

\subsection{Pembahasan}

\subsubsection{Pengaruh Budaya Organisasi Terhadap Komitmen Organisasional}

Dari hasil uji statistik dapat diketahui bahwa budaya organisasi berpengaruh signifikan terhadap komitmen organisasional karena nilai Sig. sebesar 0,000<0,05. Keterkaitan antara budaya organisasi dan komitmen organisasional juga dikemukakan oleh Robbins (2016:282) bahwa suatu budaya yang kuat akan memperlihatkan kesepakatan yang tinggi mengenai tujuan organisasi di antara anggota-anggotanya. Kebulatan suara terhadap tujuan akan membentuk keterikatan, kesetiaan, dan komitmen organisasi. Dengan kata lain, karyawan tidak pernah lepas dari nilai-nilai budaya sebagai pedoman mereka dalam bekerja dan bertingkah laku di dalam organisasi. Kecocokan nilai budaya menimbulkan suasana kondusif bagi pegawai dalam menjalankan aktivitas kerjanya. Budaya organisasi yang kondusif, akan menimbulkan komitmen yang kuat dari pegawai terhadap organisasi.

Berdasarkan definisi dari Mathis \& Jackson (2012), Komitmen organisasional adalah tingkat sampai di mana karyawan yakin dan menerima tujuan organisasi, serta berkeinginan untuk tetap tinggal di dalam organisasi tersebut. Tujuan organisasi sendiri merupakan perwujudan dari nilai-nilai yang digunakan dan diyakini oleh setiap anggota organisasi. sedangkan nilai-nilai organisasi merupakan budaya organisasi itu sendiri seperti yang dijelaskan Sangadji \& Sopiah (2013), bahwa budaya perusahaan adalah sekumpulan nilai dan pola perilaku yang dipelajari, dimiliki bersama oleh semua anggota organisasi dan diwariskan dari satu generasi ke generasi lainnya.Dari hasil penelitian diperoleh hasil bahwa budaya organisasi berpengaruh terhadap komitmen organisasional. Hasil ini sejalan dengan hasil penelitian yang dilakukan oleh Tumbelaka, AlHabsji, \& Nimran (2016), hasil penelitiannya menyimpulkan bahwa budaya organisasi berpengaruh signifikan positif terhadap Komitmen Organisasional.

\subsubsection{Pengaruh Budaya Organisasi Terhadap Intent to Leave}

Dari hasil uji statistik dapat diketahui bahwa budaya organisasi berpengaruh signifikan terhadap intent to leave karena nilai Sig. sebesar $0,000<0,05$. Seperti yang telah dikemukakan sebelumnya bahwa menurut Mathis \& Jackson (2012), budaya merupakan hal yang penting dalam mempertahankan karyawan, hal senada juga dikemukakan oleh Luthans (2012) bahwa ada analisis terbaru dari perusahaan fortune yang menemukan bahwa atribut yang paling berhubungan dengan mereka yang menduduki peringkat tiga teratas dalam industri adalah "menarik dan mempertahankan orang-orang yang punya talenta mengagumkan". Cara yang dilakukan perusahaan tersebut adalah menanggapi budaya dan nilai mereka secara serius.

Setiap anggota di dalam organisasi mempunyai impian dan harapan, mempunyai pokok persoalan dan masalah. Mereka ingin berhasil dalam bekerja dan memberikan kontribusinya kepada organisasi. Pemenuhan harapan, keinginan dan kesesuaian nilai akan menciptakan energi, rasa bangga, kesetiaan dan gairah. Kesemuanya ini memberikan warna yang kuat kepada budaya kerja, juga kepada budaya organisasi. Hal inilah yang mempengaruhi keinginan karyawan untuk bertahan atau keluar dari perusahaan tempatnya bekerja. Kalau impian dan harapan yang diinginkannya tidak tercapai di dalam perusahaan, maka keinginan keluar lebih kuat lagi sehingga mempengaruhi bagaimana pola maupun budaya kerjanya karyawan tersebut selanjutnya. Dari hasil penelitian diperoleh hasil bahwa budaya organisasi berpengaruh terhadap intent to leave. Hasil ini sejalan dengan hasil penelitian yang dilakukan oleh Mustika, (2012), hasil penelitiannya menyimpulkan bahwa budaya organisasi berpengaruh signifikan positif terhadap intent to leave. 


\subsubsection{Pengaruh Komitmen Organisasional Terhadap Intent to Leave}

Dari hasil uji statistik dapat diketahui bahwa komitmen organisasional tidak berpengaruh signifikan terhadap intent to leave karena nilai Sig. sebesar 0,069>0,05. Komitmen yang kuat terhadap organisasi akan menjadi bahan pertimbangan bagi karyawan untuk meninggalkan organisasi. Kebulatan suara terhadap tujuan akan membentuk keterikatan, kesetiaan, dan komitmen organisasi. Kondisi ini selanjutnya akan mengurangi kecenderungan karyawan untuk keluar dari organisasi (Robins, 2014). Perluasan komitmen organisasional yang logis khususnya fokus pada faktor-faktor komitmen yang kontinu, yang mengungkapkan bahwa keputusan untuk tinggal bersama atau meninggalkan perusahaan pada akhirnya tercermin dalam ketidakhadiran dan angka perputaran karyawan. Hal ini cukup beralasan, karena jika organisasi menurut penilaian seseorang mampu memberikan kepuasan kerja, maka komitmen organisasional terbentuk sebagai ungkapan kepuasan individu terhadap organisasi. Komitmen organisasional yang terbentuk dalam diri seseorang akan membuatnya tetap bertahan dalam organisasi dan tidak memiliki keinginan pindah ke organisasi lainnya.

Dari hasil penelitian diperoleh hasil bahwa komitmen organisasional tidak berpengaruh terhadap intent to leave. Hasil ini sejalan dengan hasil penelitian yang dilakukan oleh Adhi dan Sugiono (2013), hasil penelitiannya menyimpulkan bahwa komitmen organisasional tidak berpengaruh signifikan positif terhadap intent to leave.

\subsubsection{Pengaruh Budaya Organisasi Terhadap Intent to Leave melalui Komitmen Organisasional}

Dari hasil uji statistik dapat diketahui bahwa tidak terdapat pengaruh signifikan budaya organisasi terhadap intent to leave melalui komitmen organisasional karena nilai Sig. sebesar $0,054>0,05$. Komitmen yang kuat terhadap organisasi akan menjadi bahan pertimbangan bagi karyawan untuk meninggalkan organisasi. Kebulatan suara terhadap tujuan akan membentuk keterikatan, kesetiaan, dan komitmen organisasi. Kondisi ini selanjutnya akan mengurangi kecenderungan karyawan untuk keluar dari organisasi (Robins, 2014). Perluasan komitmen organisasional yang logis khususnya fokus pada faktor-faktor komitmen yang kontinu, yang mengungkapkan bahwa keputusan untuk tinggal bersama atau meninggalkan perusahaan pada akhirnya tercermin dalam ketidakhadiran dan angka perputaran karyawan.

Penelitian ini ditujukan untuk memberikan justifikasi ilmiah bagaimana pengaruh budaya organisasi terhadap intent to leave karyawan melalui komitmen organisasi. Juga menyajikan model baru dan membuktikan secara empirik bahwa budaya organisasi secara signifikan berpengaruh terhadap intent to leave karyawan, yang mengacu pada pandangan Vanderberg (2007) bahwa terdapat hubungan antara budaya dengan labor turnover. Penelitian ini juga ditujukan untuk memberikan justifikasi ilmiah yang akan menjawab adanya pengaruh langsung komitmen terhadap intent to leave karyawan. Temuan yang didapatkan dalam penelitian ini, yaitu adanya pengaruh antara komitmen dengan intent to leave juga memperkuat teori, di mana secara lebih lanjut diuraikan bahwa komitmen karyawan ini diindikasikan melalui komitmen afektif, komitmen kontinuan dan komitmen normatifnya. Dengan demikian hasil-hasil penelitian ini secara keseluruhan memperkuat teori sebelumnya dan bahkan menemukan kombinasi antara budaya organisasi yang dipertemukan dan komitmen untuk dilihat pengaruhnya terhadap intent to leave karyawan. Budaya organisasi menjadi hal yang sangat penting sebagaimana kondisi nyata pada obyek di mana penelitian dilakukan.Dari hasil penelitian diperoleh hasil bahwa budaya organisasi berpengaruh tidak signifikan terhadap intent to leave melalui komitmen organisasional. Hasil ini sejalan dengan hasil penelitian yang dilakukan oleh Mustika (2012), hasil penelitiannya menyimpulkan bahwa budaya organisasi tidak berpengaruh terhadap intent to leave melalui komitmen organisasional. 


\section{Kesimpulan dan Rekomendasi}

\subsection{Kesimpulan}

Kesimpulan dalam penelitian ini adalah :

a. Budaya organisasi berpengaruh positif dan signifikan terhadap komitmen organisasional pada PT. Fast Food Indonesia Tbk. Medan.

b. Budaya organisasi berpengaruh positif dan signifikan terhadap intent to leave pada PT. Fast Food Indonesia Tbk. Medan.

c. Komitmen organisasional berpengaruh tidak signifikan terhadap intent to leave pada PT. Fast Food Indonesia Tbk. Medan.

d. Tidak terdapat pengaruh langsung antara budaya organisasi terhadap intent to leave melalui komitmen organisasional pada PT. Fast Food Indonesia Tbk. Medan

\section{2. $\quad$ Rekomendasi}

Saran dalam penelitian ini adalah :

a. Pimpinan harus lebih bisa berinteraksi dengan karyawan supaya bisa menjelaskan secara rinci standar etika yang berlaku bagi setiap karyawan dalam melaksanakan tugas, agar karyawan dapat menilai bentuk kegiatan yang diinginkan dan membantu memberikan pertimbangan jika menemui keraguan dalam bertindak, sehingga karyawan cenderung lebih yakin lagi dalam memberikan maupun menciptakan ide-ide baru yang berguna bagi perusahaan. Bagi pihak perusahaan, diharapkan dapat terus mengembangkan dan mempertahankan efikasi-diri karyawannya dengan cara memberikan pembinaan melalui pelatihan-pelatihan yang dapat mengembangkan efikasi-diri karyawannya, supaya dengan efikasi diri yang tinggi, karyawan dapat mengembangkan konsep berpikir bahwa peraturan yang dibuat oleh perusahaan adalah suatu skenario-skenario sukses yang memberikan tuntunan positif dan dukungan untuk memperoleh hasil yang diharapkan oleh karyawan.

b. Diharapkan pihak perusahaan untuk memperhatikan komitmen organisasionalnya, apakah sudah merasa senang atau tidak dengan segala fasilitas yang mereka peroleh. Hal ini akan mempengaruhi sikap dan tingkah laku mereka dalam bekerja.

c. Perusahaan perlu lebih memberikan dukungan terhadap karyawan dalam memberikan ide-ide baru dan inovasi, serta menghargai pengambilan resiko yang dilakukan oleh karyawan, selain itu juga perusahaan perlu memperhatikan dampak dari keputusankeputusan yang dihasilkan perusahaan terhadap karyawan.

d. Dari hasil analisis deskriptif variabel budaya organisasi terlihat bahwa karyawan masih merasa bahwa perusahaan belum memperhatikan dampak keputusan-keputusan perusahaan terhadap karyawan sehingga dukungan karyawan terhadap perubahan peraturan di dalam perusahaan dipersepsikan rendah oleh karyawan yang menjadi responden. Dengan memperhatikan hal tersebut diharapkan dapat meningkatkan juga dukungan karyawan terhadap perubahan-perubahan peraturan di dalam perusahaan, dengan begitu dapat lebih memperkuat budaya organisasi yang ada sehingga meningkatkan kepuasan kerja dan komitmen karyawan terhadap perusahaan. Komitmen organisasional karyawan yang tinggi menumbuhkan loyalitas dan rasa memiliki karyawan kepada perusahaan yang nantinya dapat mengurangi niat karyawan untuk keluar dari perusahaan. 


\section{Daftar Pustaka}

Armstrong, M. (2016). Handbook of Human Resources Management. In M. Zeuch (Ed.), Handbook of Human Resources Management. https://doi.org/10.1007/978-3-662-44152-7

Luthans, F. (2012). Organizational behavior an evidence-based approach 12th edition. In Organizational behavior: an edivence-based approach.

Mangkunegara. (2011). Manajemen Sumber Daya Perusahaan. In Manajemen Sumber Daya Perusahaan.

Mathis, R. L., \& Jackson, J. H. (2012). Manajemen Sumber Daya Manusia. In Manajemen Sumber Daya Manusia.

Mustika, I. K. (2012). Analisis Budaya Organisasi dan Kepuasan Kerja Melalui Komitmen Pengaruhnya Terhadap Intent to Leave Karyawan pada Industri Jasa Perhotelan di Kabupaten Badung dan Kota Denpasar. 3(1), 1-24.

Prihartono, R. W. (2013). Pengaruh Kepuasan Kerja Terhadap Komitmen Organisasi Dan Turnover Intention Pada Karyawan PT. Rentokil Initial Surabaya. Jurnal Ilmu Manajemen, 1(3), 931-944.

Robbins, S. P., \& Judge, T. A. (2014). Perilaku Organisasi Edis Ke-16. Salemba.

Robins, stephen. p. (2014). Teori Budaya Organisasi. Perilaku Organisasi.

Sangadji, E. M., \& Sopiah. (2013). Perilaku Konsumen : Pendekatan Praktis Disertai Himpunan Jurnal Penelitian. Yogyakarta: Penerbit Andi.

Siswanti, Y. (2006). Pengaruh Pemediasian Komitmen Organisasional Dalam Hubungan Antara Kepuasan Kerja Dan Intent to Leave Studi pada Rumah Sakit di Yogyakarta. BENEFIT, 10(2), $142-154$.

Sobirin, A. (2019). Budaya organisasi : Pengertian, Makna dan Aplikasinya Dalam Kehidupan Organisasi (Edisi Ke-3). Yogyakarta: UPP STIM YKPN.

Sugiyono. (2012). Metode Penelitian Kuantitatif, Kualitatif dan R \& D.Bandung:Alfabeta. Metode Penelitian Kuantitatif, Kualitatif Dan R \& D.Bandung:Alfabeta. https://doi.org/10.1017/CB09781107415324.004

Tumbelaka, S. S. X., AlHabsji, T., \& Nimran, U. (2016). Pengaruh Budaya Organisasi terhadap Kepuasan Kerja, Komitmen organisasional dan Intention to Leave (Studi pada Karyawan PT.Bitung Mina Utama). Jurnal Bisnis Dan Manajemen, 3(1), 94-108. 
